\title{
Status and Challenges of Social Competence Education in Korean Sports Pedagogy: Past, Current, and Future
}

\author{
Soon-Mook Cho \\ President of KASP, Korea National \\ University of Education
}

\section{Introduction}

While the level of the social, cultural, financial, and mental stress that the youth face in modern society is increasing, the traditional role of community to protect, raise, and make it possible for these youths to be able to adapt to community is gradually fading (Burlak et al., 2011). While the dependence and expectations on schools are increasing, the function of school education is limited, and there are those who say that it is retrograding. For example, as the opportunities to collaborate with people decrease as students move up to higher education, dangerous behavior such as stress, violence, oppression, drugs, and sex that threaten social growth is expanding (Benson, 2006; Blum \& Libbey, 2004; Klem \& Connell, 2004). This is a counterevidence showing that school education does not contribute to strengthening students' social competence, and it is a reason why school need to restore social function.

The education circle's efforts to strengthen students' social competence is unlike the concept and it has been suggested constantly. Traditionally for sociality, there were social attitude and affective education, and recently there has been education focusing on emotion, that is behind psychological functioning, such as emotional intelligence, emotional regulation skill, and social emotional learning education.

On the other hand, many studies are reporting that sports activity has a great value in social-emotional competence development, and it is as follows. First, various studies about psychological levels report that participating in sports activity (or physical activity) decreases negative psychological factors (Ex. violent behavior, stress and negative mood states, alienation and delinquency, deviant behavior, etc.)(Gan, 2003; Go \& Jung, 1998; Seo, 2003; Yu \& Won, 2007, 2008 etc.) and increases positive psychological factors (Cohesiveness, commitment, collaborative decisionmaking, emotional intelligence, positive peer relationships, etc.)(Kang \& Choi, 2000; Kim, etc., 2004; Jung \&, Choi, 1997; Choi\& Yu, 2011; Choi \& Kim, 2011, etc.). Second, studies that shed light on semantic experiences through qualitative research showed that sports activity enhanced the sprit of challenge in youths, provided reflective experiences that included co-existence, communication and depth, and provides bliss that is much more than just the experience when success was achieved (Kim, 1999; Park, 2006; Lee, etc., 2008; Arcand et. al., 2007; Hansen \& Parker, 2009; Fave et. al., 2003; McNamee \& Steffen, 2001; West \& Allin, 2010). Third, according to studies dealing with treating subjects with psychological disorders with physical activity programs, physical activity was effective for students with ADHD (Kim, etc., 2006; Lee \& Lee, 2010), and people with emotional disorders(Kim \& Jang, 2003; Lee, etc. 2006).

What educational mechanism of sports activity makes this kind of value possible? Studies recently reported on Korean sports education world sheds light on this on personality aspect, emotional aspect, 
and neurophysiological aspect. First, in the personality aspect, sports activity has an educational mechanism that can internalize personalities such as impartiality, loyalty, cooperation, courage, determination, commitment, self-control, and patience (Choi \& Park, 2011; Choi, 2010; Feezell, 2004; McFee, 2004). Second, in the emotional aspect, the emotional effect of sports activity is proven according to the endocrine (hormonal) change theory, generalized stress theory, and the secession theory (Lee, 2012). Third, in the neurophysiological aspect, physical activity directly and indirectly affects the frontal cortex that manage the social and emotional executive functioning, enhances the emotional state and on the cellular level it enhances the potential of neurons to positively affect the self control ability related to cognitive and emotional areas (Lee, 2012, 2012).These evidences prove that sports activity is the ideal activity for the youths' social/ emotional competence education.

Korean sports education has been generally developed focused on school physical education. As a result, in the research fields, sports activity's social competence education has been conceptualized as part of education terminology. For example, there are traditionally conceptualized affective domain education or correct social attitude education, and there is personality education that has been introduced recently. Because of the inclusiveness of the concept of affective/ social attitude and personality, it is useful in uncovering the direction of education in the levels of philosophy and objectives, but there is a limit to securing authenticity of education like the content or methods of the education. Therefore, in this level of concepts, it is difficult to uncover the reality of social competence education through sports, that our society demands. On this basis, Korean sports education world in the future need alternative concepts that will guideline the reality of education.

Therefore this study follows the conditions of the Korean sports education's social competence education through sports activity, find out about what has been suggested as problems, reflects upon what the current meaning and limits are, and tries to suggest directions for the future.

\section{Past (Era of affective education): Education with objective but no substance}

In the early 1960's. the new government (3rd Republic) emphasized fitness education under the catch phrase of "Fitness equals national power." Naturally, school physical education focused on physical strength promotion. The concept of fitness in this is not just for fitness of the body but also for mental strength. As such, fitness education in school physical education put its purpose on cultivating mental strength and sense of public order while building physical strength.

As the 6th physical education department curriculum period came, the department's education objective was divided into three following Blum's objective classification system. As a result, affective domain education was officially set as an objective for the first time. In a period when people in the major of physical education was scarce, the objective of affective domain education was unclear in the level of common sense, and the academic establishment about what (content to teach and how (method) to teach was not attempted. In this kind of atmosphere the affective domain education in physical education was only seen as a study cultivating team spirit, sense of order, cooperativeness, and sociality, and in reality, affective domain education was not being done in a serious sense.

In the 7th physical education department curriculum during the late 1990's was a curriculum that had an academical basis on another national level physical education department curriculum. For the first time the nature (philosophical discussion) of physical education department was suggested, a certain portion of curriculum domain was set, and an effort to promote positive change of the field of physical education was attempted. In the 7 th physical education department curriculum document, it is suggested that the ratio of assessment domain to be '20:70:10,' in respect to 'theory: knowledge: attitude.' However, most physical education teachers reflected 
10 out of 100 points to attitude and used a minus system where violation of set regulation or misdeed was given penalty points. In the end, affective domain education was degenerated into a system that regulated students' behavior with points.

There are very few studies that show the reality of affective domain education before the 2000's. Only a few academic research papers show the reality of it and representatively, there are studies by Kwon \& $\operatorname{Kim}(2006)$.

Until the early 2000's in Korean physical education, affective domain education was in the form of teachers using their own discretion to teach without defining the clear objective, content, or method. It therefore means that the curriculum that follows the idealogical goals of the curriculum was not established.

\section{Current (Era of personality education): Creation of objective education content and diversified approach of alternatives}

If there were two main issues of personality education covered by the Korean sports education from early 2000's to now, one is the argument of what the educational content of personal education is, and the other is the argument of how to teach personality. In this chapter, the answers that the Korean sports education world had been giving about these two questions will be looked at.

\section{Personality, what should be taught?}

Regarding the problem faced by the physical education department, Yu Jungae (2003) suggested learning domain segmentation phenomenon, biased psychomotor domain education, memorization based cognitive domain education, and the absence of affective domain education. Especially, she finds the fundamental limitation of the fourth problem in the fact that the content of the affective domain education was not being specified. On the basis of this awareness of issues, Yu Jungae (2003) suggested an alternative structure system of knowledge of physical education content as seen in $<$ Figure $1>$. As seen in $<$ Figure $1>$ she suggests that the existing knowledge, function, and attitude that was presented segmented and without system, in the context of curriculum knowledge, must be reclassified as conceptual knowledge (=propositional knowledge) and practical knowledge (=methodical knowledge, procedural knowledge). For example, attitude curriculum, regarding attitude, can be composed of conceptual knowledge and the practical knowledge that is needed in practicing such knowledge.
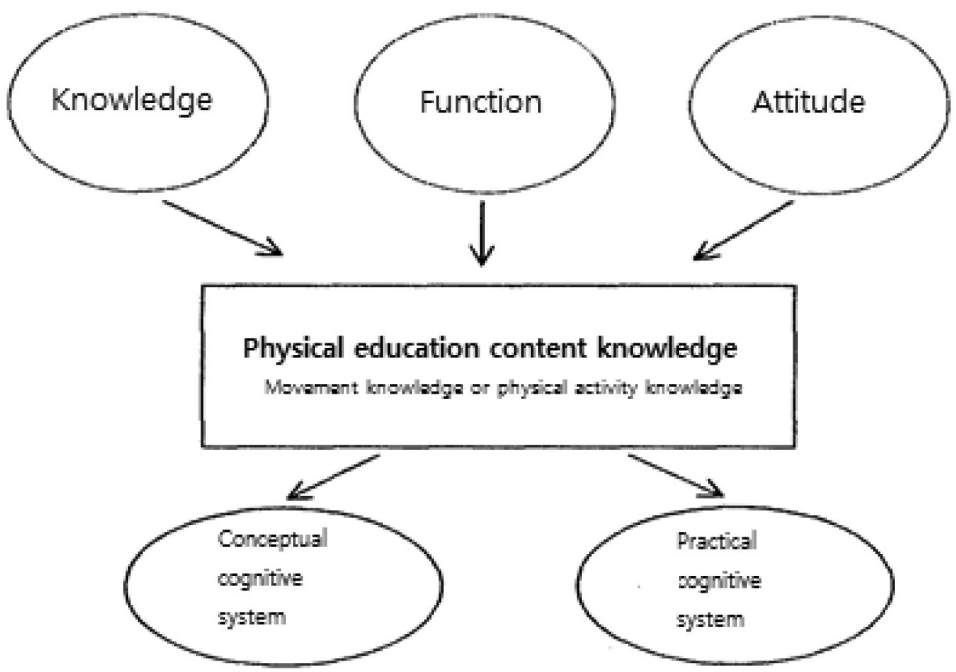

<Figure 1> Alternative structure system of knowledge of physical education content 
Choi Uichang (1999) stated that what they teach at a public educational institution called school must have proven value and that in physical education, when the public culture embedded in physical activity (or sports) is taught, the justification is given. In this case, the compilation of public culture is the personality value embedded in physical activity. The discussion of affective domain education in the objective dimension was established as a system as educational content in the 7th amendment of physical education curriculum. 7th amendment of physical education curriculum systemized physical education and the educational content as value and subject. The value embedded in physical activity was set as health, challenge, competition, expression, and leisure, and this was considered as a large domain. The large domain was divided by subject to set an intermediate domain to be taught according to each grade, and specified the content elements to be taught in each intermediate domain. Especially, personality element was included in content elements, which conceptualized personality education content for the first time. Since, the physical education curriculum was once more revised and the physical education curriculum following the 2009 revision, the problem in the 7 th amendment of physical education curriculum was supplemented to result in the physical education curriculum shown in $<$ Figure $2>$.

\begin{tabular}{|c|c|c|c|}
\hline Domain & \multicolumn{3}{|c|}{ Middle School 1 3 grade } \\
\hline $\begin{array}{l}\text { Health } \\
\text { Activity }\end{array}$ & $\begin{array}{l}\text { A. Health and environment } \\
\text { - Understanding of health } \\
\text { and enhancement } \\
\text { - Medicine and symbols } \\
\text { - Pollution and health } \\
\text {-Self control }\end{array}$ & $\begin{array}{l}\text { B. Health and fitness } \\
\text {-Understanding of fitness } \\
\text { and enhancement } \\
\text {-Understanding sex and } \\
\text { sexual assault } \\
\text {-Preventing accidents } \\
\text {-Self Respect }\end{array}$ & $\begin{array}{l}\text { C. Health and safety } \\
\text {-Exercise prescription } \\
\text {-First aid and sports injury } \\
\text {-Disasters and safety } \\
\text {-Willpower }\end{array}$ \\
\hline $\begin{array}{l}\text { Challenge } \\
\text { Activity }\end{array}$ & $\begin{array}{l}\text { A. Record Challenge } \\
\text {-Historical and scientific } \\
\text { principle } \\
\text {-Game method and } \\
\text { functions } \\
\text {-Comparison of sports and } \\
\text { appreciation } \\
\text {-Endurance }\end{array}$ & $\begin{array}{l}\text { B. Movement Challenge } \\
\text {-Historical and scientific } \\
\text { principle } \\
\text {-Game method and } \\
\text { functions } \\
\text {-Comparison of sports and } \\
\text { appreciation } \\
\text {-Confidence }\end{array}$ & $\begin{array}{l}\text { C. Target/ throwing } \\
\text { challenge } \\
\text {-Historical and scientific } \\
\text { principle } \\
\text {-Game method and } \\
\text { functions } \\
\text {-Comparison of sports and } \\
\text { appreciation } \\
\text {-Problem solving skills }\end{array}$ \\
\hline $\begin{array}{l}\text { Competition } \\
\text { Activity }\end{array}$ & $\begin{array}{l}\text { A. Territorial competition } \\
\text {-Historical and scientific } \\
\text { principle } \\
\text {-Game method and } \\
\text { creative strategy } \\
\text {-Comparison of sports and } \\
\text { appreciation } \\
\text {-Fair play }\end{array}$ & $\begin{array}{l}\text { B. Field competition } \\
\text {-Historical and scientific } \\
\text { principle } \\
\text {-Game method and creative } \\
\text { strategy } \\
\text {-Comparison of sports and } \\
\text { appreciation } \\
\text {-Teamwork }\end{array}$ & $\begin{array}{l}\text { C. Net type competition } \\
\text {-Historical and scientific } \\
\text { principle } \\
\text {-Game method and creative } \\
\text { strategy } \\
\text {-Comparison of sports and } \\
\text { appreciation } \\
\text {-Care and respect }\end{array}$ \\
\hline $\begin{array}{l}\text { Expression } \\
\text { Activity }\end{array}$ & $\begin{array}{l}\text { A. Expression of } \\
\text { appreciation } \\
\text {-Characteristics and types } \\
\text {-Expression method } \\
\text { Creative expression and } \\
\text { appreciation } \\
\text {-originality }\end{array}$ & $\begin{array}{l}\text { B. Modern Expression } \\
\text {-History and types } \\
\text {-Expression method } \\
\text { Creative expression and } \\
\text { appreciation } \\
\text {-Passion }\end{array}$ & $\begin{array}{l}\text { C. Traditional Expression } \\
\text {-History and types } \\
\text {-Expression method } \\
\text { Creative expression and } \\
\text { appreciation } \\
\text {-Multicultural respect }\end{array}$ \\
\hline $\begin{array}{l}\text { Leisure } \\
\text { Activity }\end{array}$ & $\begin{array}{l}\text { A. Society and Leisure } \\
\text { - Understanding of youth } \\
\text { leisure } \\
\text {-Every day leisure planning } \\
\text { and practice } \\
\text {-Appreciation of leisure } \\
\text { activity } \\
\text {-Interest and immersion }\end{array}$ & $\begin{array}{l}\text { B. Nature and Leisure } \\
\text {-Understanding of natural } \\
\text { leisure } \\
\text {-Natural leisure planning and } \\
\text { practice } \\
\text {-Appreciation of leisure } \\
\text { activity } \\
\text {-Co-existence }\end{array}$ & $\begin{array}{l}\text { A. Global leisure } \\
\text {-Understanding of global } \\
\text { leisure } \\
\text {-Global leisure planning and } \\
\text { practice } \\
\text {-Appreciation of leisure } \\
\text { activity } \\
\text {-Openness }\end{array}$ \\
\hline
\end{tabular}

<Figure 2> Domain in 7th amendment of physical education curriculum(2009) 
In the physical education curriculum following the 2009 revision, the personality element was conceptualized as self-control, self-esteem, willpower, patience, confidence, confidence, problem solving ability, fair play, teamwork, care and respect, creativity, passion, cultural respect, interest and involvement, coexistence, and openness. Of course, can physical activity be conceptualized in 5 kinds of values? Also there could be controversy about the reasoning behind conceptualizing mental product such as ' $\sim$ spirit' and ' attitude.' In addition, there is a large level gap between document level with is called curriculum and practice level which is called lessons, and the problem of whether the personality element conceptualized in the curriculum content system could promote the right practice of lessons can be pointed out. Even so, there is a big significance in that first, the direction of the practice of personality education has been suggested through the conceptualization of personality education content, second, the educator's potential to design personality education lessons have been maximized, and third, serious academic discussion of personality education has been made possible.

\section{Personality, how should it be taught?}

As Metzler's (2000) 'Introduction models for Physical education' was translated and published in the early 2000's, there were many different reports in the research field about physical education research cases that applied various education models. Especially, there was a big interest among researchers about sports education models, understanding focused game lesson models, and cooperative learning models, and in the field it caught much attention. With this, although not suggested in Metzler's (2000) book, social responsibility model was introduced by few researchers, and the interest in this research field was heightened.

Integrative physical education lessons combining model focused education and general method principles were emphasized. Simply speaking, integrative physical education lesson is an integration of experience methods, and it signifies teaching direct experience and indirect experience in the same physical education lesson. The 2007 amended physical education curriculum and 2010 amended physical education curriculum treats this integrative physical education methods as an important method principle in teaching and learning.

Personality education method has been brought up in this context. As prime examples, social responsibility model, lesson model developed as a part of integrative physical education lesson, and other various lesson techniques and strategies are as below.

First is the 'social responsibility model.' This model was developed to teach delinquent children in cities about responsible behavior (Hellison, 2003; Hellison \& Walsh, 2002). Since, in the process of physical education educators integrating social qualities (Respect for others, participation and effort, selfinitiative, teamwork, leadership, and social application, etc.) into physical education lessons following this model, it was amended into a physical education program fit for personality education and was spread world wide (Choi \& Park, 2011). In the responsibility model lessons, the students go through a sequence of steps, irresponsible step (step 0), individual step (step 1), participatory step (step 2), an autonomous step (step 3), and altruistic step (step 4) to mature responsible behavior and the progression from lower steps to higher steps become the process of completing the student's responsibility.

Second is the 'Hanaro lesson model.' This model introduced by Choi Uichang (1999) in the late 1990's became the most prominently applied lesson model in the next 10 years domestically. Especially, the joint effort of theory and field stands out. For example, scholars including Choi Uichang continuously developed and amended the model's theoretical foundation (Park, 2011; Choi \& Park, 2011; Choi, 2010 , etc.) and teacher researchers strengthened the practicality of the model by practicing and reflecting upon the lessons applying this model (Kim, 2011; Seo, 2007; Oh, 2008, etc.)

Third is the personality education method 
presented in various levels of lesson techniques and strategies. As a principal example, there is the spectrum of teaching styles, and cooperative teaching strategy applies in this. First, the teaching style spectrum is composed of 11 types of teaching styles (Command type, practice type, interactive type, selfcheck-type, inclusion type, guided discovery type, convergence discovery type, expanded production type, self-design type, student-led type, and selflearning type), and if up to inclusion type is a teacher led controlled type lesson, from guided discovery type, they are lesson approaches that respect the initiatives of the students. Next cooperative learning strategy is the most commonly used method to implement affective value such as cooperation. Cooperative learning is not about individual learning but composes and guides students to cooperatively experience and solve learning activities and leaning materials.

Other than the methods above, award/penalty granting, dilemma inference, modelling, and reflective teaching skills are being widely used in physical education (Jung, etc., 2007). Award/ penalty is the most basic method trying to stimulate personality cultivation through praise, points, sanctions and emotions. Dilemma inflection is a method based on Kohlberg's Stages of Moral Development theory, which is a method to practice the process of moral inflection about moral dilemmas to enhance moral judgement through solving moral conflict situations, and through this to cultivate moral behavior. Modelling uses people with initiative such as teachers, students, sports stars, and important figures as examples and by letting the students experience first hand in sports situations experiencing various roles coaches, players, umpires, etc., to evaluate their behavior by themselves. Reflective teaching method allows the students have an opportunity to reflect through reflection processes about self and lessons through lesson video analysis, making test questions, watching visual media, writing reflection diaries, discussion and debates, etc. (Choi \& Park, 2011).

The above discussions are combined and the representative physical education methods researched through personality education methods are summarized in $<$ table $1>$.

\section{Future: Developmental challenges aimed at evidence based social/ emotional technique education}

Until now sports education scholars in Korea have been striving to convert personality education through sports without content or method into 'education that has' content and method. Through this effort they have been suggesting the framework and practical direction of curriculum design. There are however some limitations, and looking at this from the point of content and method, it is as follows.

First, from the perspective of content, it is the problem of whether the derived personality concept is within the range of practical education. According to Hauenstein(1998) who presented the lesson system of affective domain, the input content for affective domain lessons presented are symbolic information and prescriptive information. First, symbolic information is a conceptual signal and

<Table 1> Representative PE methods on research in personality education

\begin{tabular}{l|l}
\hline & \multicolumn{1}{c}{ Content } \\
\hline Lesson technique & $\begin{array}{l}\cdot \text { Experience learning and cooperative experience, interactive lesson style, } \\
\text { sportsmanship lesson technique, etc. }\end{array}$ \\
\hline Lesson strategy and program & $\cdot$ Cooperative learning strategy, STAD, TGT DirectISmallI Etc. \\
\hline Teaching model & $\cdot$ Social responsibility model, sports education model \\
\hline Climatic environment creation & $\cdot$ Method to cultivate virtue called habituation, socialization, culturization, etc. \\
\hline Integrative approach & $\cdot$ Integrate with humanistic physical education \\
\hline
\end{tabular}


symbolic tool that can be applied in all information and knowledge, and it signifies symbols, signs, written language spoken language, sound, form, feeling, smell, taste, etc. This relates to the perception of emotional information that can be obtained from the environment in certain conditions. Next, prescriptive information is a concept having the function of materializing normative existence (what ought to be), and it is a systemization of values and beliefs about normative good, evil, beauty, unattractive, righteousness, error, bliss, pain, truth, happiness, sadness, etc. or a point within the two extremes. The content that becomes the value determination standard applies here. The personality elements that Korean national level physical education and curriculum proposes prescriptive information content but is not able to propose the content of the former content. Experience is determined by the subjective interpretation of information obtained from the environment (Lee Hanwoo Cltd. 2005). Especially, all experiences are created based on emotion but emotional experience is crucially determined by physical, social, and perceived psychological environment (attach reference). In this respect, to strengthen the practicality of established education content, content establishment about symbolic information is required.

Second, in regards to method, there is a problem that current methodical approach is not able to specify a leaning process. Methodical approaches currently being applied in korean sports education field, for example, social responsibility model, Hanaro lesson model, or methods being presented in the strategical level explain the system of methods as outlines but it is unable to implement a detailed learning process for forming students' attitude.

In summary, currently in the Korean sports education research domain there is significance that the systematic framework for sociality education through sports has been established, but relatively the discussion about what and how to practice this in reality, thus small system establishment discussion is lacking. In this chapter, the aim is to find the alternative for these limitations in 'emotion' and 'team.'

\section{Practical content organization}

In the field of educational psychology, the theoretical discussion for using emotion in education have been diversely put forward since mid, late 1990's. Especially, as the theory of emotional intelligence was presented, practical research has been vitalized. Zimmerman(1989), based on the self adjustment theory, explains the emotional adjustment process as 'Personal internal adjustment phase,' behavior adjustment phase,' and 'environment self adjustment phase.' First in the personal internal adjustment phase, the identity of expressed emotion by monitoring is objectively checked to accurately recognize emotion. Second, in the behavior adjustment phase, a specific behavior coping strategy is created, and the difference is that unlike environmental self adjustment, the strategy is created on the personal level. According to each person's objective, coping strategy is largely seen as 'approach' type and 'avoidance' type. Third, environmental self adjustment phase is a phase where emotional adjustment is made not for the self but for the conformation to social situations, and people are to understand and act in situations in society's, thus others', point of view.

Social Emotional Learning theorists, based on these emotional adjustment phases, convert this into action terminology fit or learning situations. As a prime example, accoring to the studies from Payton, Wardlaw, \& Graczyk(2000) and Zins, Weissberg, Wang, \& Walberg(2004), in the personal level strategy creation phase, self awareness and self management technique is required, and in the phase acting in the societal point of view, the person needs social awareness, interpersonal skills, responsible decision making techniques. Kenneth, Merrell, Barbara, \& Gueldner(2010), who summarized the above argument, summarizes the elements that enhance social emotional ability in $<$ Table $2>$.

The main elements of the program that the social 
<Table 2> Principal component enhancing social emotional learning

\begin{tabular}{l|l}
\hline Self awareness & $\begin{array}{l}\text { To be aware of one's emotions, accurately perceive self, be aware of oneself's strengths, needs, } \\
\text { and value, to create self efficacy, recognizing oneself's position in this world in the relationship } \\
\text { with an entity with higher power and much bigger creative potential, etc. }\end{array}$ \\
\hline Self management & $\begin{array}{l}\text { Controlling impulse, managing stress, self synchronizing, disciplining personal needs, adequate } \\
\text { goal setting, etc. }\end{array}$ \\
\hline Social awareness & $\begin{array}{l}\text { Being able to be in others' shoes and empathizing, understanding human plurality, respecting } \\
\text { others, separating personal and group objectives, etc. }\end{array}$ \\
\hline $\begin{array}{l}\text { Interpersonal } \\
\text { skills }\end{array}$ & $\begin{array}{l}\text { Communicating, socially interacting, creating friendly relationships, settling dispute, finding } \\
\text { ways to get help from surroundings, etc. }\end{array}$ \\
\hline $\begin{array}{l}\text { Responsible } \\
\text { decision making }\end{array}$ & $\begin{array}{l}\text { Evaluating problematic situations, applying effective problem solving technique, considering } \\
\text { and evaluating various alternatives, setting moral standards, objectively making decisions, etc. }\end{array}$ \\
\hline
\end{tabular}

emotional learning theory raises and the contents of the program developed based on it provides ideas to the content system of social competence education through sports. If for instance the inherent spirit in sports such as fair play, leadership \& followship, empathy, caring, patience, willpower,etc. is as expressed by Hauenstein(1988), it becomes prescriptive information to take the role of a standard of behavior. Although each sports spirit is oriented towards the same thing, the composition is different. The reason why it is different is because the induced emotions and the methods to control them are different. In situations where fair play is required and another where empathy is required, the induced emotion is different in each situation. Also, the methods to control emotion in appropriate situations are a bit different. Therefore, by filling in the puzzle pieces of techniques required for each representative emotion inducing situations and emotion control processes, the derivation of appropriate education content fit for actual teaching circumstances can be made possible.

\section{Team learning process design}

When focusing on social competence education, one thing that cannot be overlooked is the fact that sport is a team activity. Where a group is defined as more than two individuals connected by social relation, a team is a group sharing an objective
(Forsyth, 2006). Because a team shares and objective, a team is a living organism, and it has a characteristic of being interactive while being also dependent. Thus, a team is something that multiple people make up a team, strive for a common goal, make unique standards and communication patterns, and change/ develop while they have conflicts and reflections, like an organism evolves. In result, because sports activity has these attributes, education of this can be translated into culminating a righteous attitude.

How must education to enhance 'team properties' be made? On the basis of team dynamics theory the people studying team sports education theory answers this question from 3 perspectives (Lee Byungjun, 2013; Henry, Arrow \& Carini, 1999).

First, in team sports education, it should be kept in mind that the basic premise is 'team.' In team sports education, as shown in the table below, the most important challenge is the social competence education created in the meeting point between team and sport. Thus it is not the separate education of team (simple cooperation without sport basis) and sport (sports strategies or techniques without team properties) but the education of social competence through sports education based on team. Fidelity to this basic premise can be kept when the agreement to five basic assumptions can be met, 1) team and sports activity must be educated in combination, 2) teams must be formed considering challenges and roles, 3 ) 
the learning of team must be maintained from start to finish, 4) social emotional techniques must be experienced through the main concepts and strategies of team sports education, 5) the evaluation in team sports activity must evaluate the overall process of the team activity.

Second, team learning process adequately reflecting team dynamics is configured. Learning processes largely consists of team building, team becoming, and team developing, and each process in then configured in more detailed steps or strategies. In team building process, team identity creation and team structure making happens. Team becoming process focuses on team objective setting and communication, and team conflict resolution is included. Team developing consists of team conflict resolution and team reflection (Refer to Table 3). This series of processes lead students to acquire social emotional skills in team sports education.

Third, team learning is integrated in the context of sports. Looking at the approach method of team football (sports) education proposed by Lee Byungjun
(2013) as an example, he, in consideration of the context of sports, integrates football lead-up game and practice, football transfiguration game and practice, and competitive football game and team learning process (Team making, becoming, developing). Looking at the process and strategies of each lessons, it is as shown in $<$ Table $4>$ below.

For students to acquire social emotional techniques within team sports education, it is assumed that, in the context of sports, the team's main concepts and strategies must be experienced. To practice this type of education, the educator must decide what to prioritize. If sports technique or strategy is to be prioritized, then traditional sports education should be taught. However if the goal is to make students into good people and for them to learn social life and sociality, there is a need to design an appropriate learning process and practice it. Of course, this is in the context of sports.

In this way team sports education provides basic ideas to design detailed learning processes using sociality education through sports. By integrating

\section{$<$ Table $3>$ Step of team learning process in cooperative learning}

\begin{tabular}{|c|c|c|}
\hline $\begin{array}{l}\text { Process } \\
\text { of } \\
\text { education }\end{array}$ & Detailed steps & Behavior terminology \\
\hline \multirow{2}{*}{$\begin{array}{l}\text { Making } \\
\text { teams }\end{array}$} & $\begin{array}{l}\text { Creating team } \\
\text { identity }\end{array}$ & $\begin{array}{l}\text { This step takes on the form of being able to feel emotions about the team and being } \\
\text { able to depend on each other, and it is a step where sense of kinship and belonging is } \\
\text { recognized }\end{array}$ \\
\hline & $\begin{array}{l}\text { Making team } \\
\text { structure }\end{array}$ & $\begin{array}{l}\text { This is a step where the unique team rules and individual roles needed in team } \\
\text { activity is defined, role distributing and making team rules takes place }\end{array}$ \\
\hline \multirow{2}{*}{$\begin{array}{l}\text { Being a } \\
\text { team }\end{array}$} & $\begin{array}{l}\text { Selecting team } \\
\text { objective }\end{array}$ & $\begin{array}{l}\text { This is a step where the members decide upon the ideal objective that can be } \\
\text { achieved through common effort, and according to time, short, medium, and long } \\
\text { term goals can be set }\end{array}$ \\
\hline & $\begin{array}{l}\text { Team } \\
\text { communication }\end{array}$ & $\begin{array}{l}\text { This is a step where communication happens for effective team activity, and learning } \\
\text { of techniques important in social life such as human relation, sense of community, } \\
\text { team configuration, and maintenance }\end{array}$ \\
\hline \multirow{2}{*}{$\begin{array}{l}\text { Team } \\
\text { growth }\end{array}$} & $\begin{array}{l}\text { Resolving team } \\
\text { conflict }\end{array}$ & $\begin{array}{l}\text { Team conflicts occur naturally in the team's developmental stage and it is an } \\
\text { opportunity for a better development, and in this step learning of how to see the } \\
\text { conflict and hot to solve the perspective of the conflict and the conflict itself }\end{array}$ \\
\hline & Team reflection & $\begin{array}{l}\text { Team reflection is an act of looking back at things that happened in the process } \\
\text { of team activity, and it is a crucial mechanism for students to learn social skills. } \\
\text { Through reflection communication skills, empathy, listening, conflict resolving and } \\
\text { other skills can be confirmed and reorganized. }\end{array}$ \\
\hline
\end{tabular}


$<$ Table 4> Instructional process and strategies in team football

\begin{tabular}{|c|c|c|}
\hline Lessons & Strategy & Football lesson activity \\
\hline $1-3$ & $\begin{array}{l}\text { Team identity creation: Making team name and song } \\
\text { Team structure creation: Distributing team roles, setting } \\
\text { communication rules within team }\end{array}$ & $\begin{array}{l}\text { Lead-up game activity } \\
\text {-Ball carrying activity, shadow game, ball } \\
\text { possesion game, } 5: 2 \text { pass game }\end{array}$ \\
\hline $4-9$ & $\begin{array}{l}\text { Team communication: Announcing prohibited words within } \\
\text { team, speaking and replying positively } \\
\text { Setting team objective: Setting individual objective, team } \\
\text { objective } \\
\text { Managing team conflict: Conversion of thought, writing } \\
\text { declarations }\end{array}$ & $\begin{array}{l}\text { Transconfigured game activity } \\
-3: 3 \text { pass game, area football game, } 6: 6 \text { mini } \\
\text { game, } 6: 6 \text { position game, } 6: 6 \text { target student } \\
\text { game }\end{array}$ \\
\hline $10-15$ & $\begin{array}{l}\text { Repetition and integration of main concepts } \\
\text { Official game courtesy development } \\
\text { Expanding main concepts between teams }\end{array}$ & $\begin{array}{l}\text { Official game activity } \\
-6: 6 \text { game }\end{array}$ \\
\hline
\end{tabular}

the content organization based on social emotion education theory proposed above with team sports learning process, a more developed sociality education through sports will be completed.

\section{Conclusion}

Until now in Korea, there have been efforts to strengthen social competence through sports education focused on school physical education. That concept has been transforming due to social attitude education, affective domain education, and personality education. However because this concept is much too inclusive, there are limitations in acquiring authenticity such as curriculum or methods. Accordingly, this study proposed the direction of establishment of education content from a social emotional education perspective, and proposed a team sports learning system based on team dynamics theory.

In the current situation where society is becoming tougher and when schools are not able to adequately do their roles in this situation, the social need for sports activity is becoming stronger. What direction must sports education be heading? There is a need to answer this question seriously. Is it fitness and health? Or is it to teach techniques well to enable people to enjoy sports for all their lives? Is it an invitation or introduction into sports culture? Many purposes of sports education can be discussed. However, the thing to focus here is that the personality and the social competence that it consists of is not the objective of one domain but the ultimate goal that sports or physical education must be oriented towards. 